\title{
MENGHINDARKAN REMAJA DARI PENYALAHGUNAAN NARKOBA MELALUI INTERVENSI IDENTITAS
}

\author{
Nanik Yuliati \\ Unversitas Jember \\ email: nanikyuliati@gmail.com
}

\begin{abstract}
Abstrak
Tulisan ini dimaksudkan untuk memberikan suatu model kerangka kerja konspetual guna menghindarkan kaum remaja dari penyalahgunaan narkoba dengan menggunakan pendekatan perkembangan. Pencarian identitas merupakan salah satu aspek perkembangan psikososial yang sangat krusial pada periode remaja dan banyak ahli perkembangan yang sependapat bahwa perkembangan kepribadian yang sehat dan/atau tidak sehat dapat diatribusikan dengan proses pencarian identitas. Para ahli perkembangan memiliki keyakinan bahwa remaja mencapai yang identitas cenderung memperlihatkan perilaku yang sehat dan konstruktif, sedangkan yang gagal mencapai identitas menjadi rentan terhadap berbagai bentuk gangguan psikososial, salah satunya penyalahgunaan narkoba. Oleh karena itu, untuk menghindarkan para remaja dari penyalahgunaan narkoba dapat dilakukan dengan cara membantunya mencapai identitas.
\end{abstract}

Kata kunci: remaja, penyalahgunaan narkoba, identitas, dan intervensi

\begin{abstract}
This paper intended to give a conceptual framework in order to prevent adolescent from drug abuse by using a developmental approach. Search for identity is one aspect of psychosocial development which very crucial in periods of adolescence and most developmentalist which agree that healthy or unhealthy personality developmental be attributable to the process of search for identity. Most developmentalist have a belief that adolescents achieve a sense of identity tend to demonstrate a healthy and constructive behavior, while failing achieve becoming vulnerable to various forms of psychosocial disturbance, one of which drug abuse. Therefor, to prevent teenagers from drug abuse we can do with helping them to achieve a sense of identity.
\end{abstract}

Keywords: adolescence, drug abuse, sense of identity, and intervention

\section{PENDAHULUAN}

Penyalahgunaan narkotika dan obat-obatan terlarang (narkoba) di kalangan para generasi muda, khususnya oleh para siswa sekolah menengah telah dinyatakan sebagai suatu masalah bangsa dan oleh karenanya perlu untuk mendapatkan perhatian dan penanganan yang lebih serius. Berdasarkan laporan dari berbagai media massa, tulis maupun elektronik, dapat disinyalir bahwa penyalahgunaan narkoba di kalangan generasi muda memperlihatkan grafik yang terus meningkat. Sepuluh tahun yang lalu, salah seoramg staf ahli Badan Koordinasi Narkotik Nasional, Padmohudojo, dalam suatu seminar di kampus Institut Teknologi Bandung menyatakan bahwa jumlah korban narkoba pada tahun-tahun ini (maksudnya hingga tahun 2001) meningkat sebesar enam kali lipat (Pikiran Rakyat, 7 Desember, 2001). Berdasarkan pada data tersebut, Padmohudojo memandang bahwa narkoba telah menjadi masalah bangsa karena merusak generasi muda. Aisyah Dahlan, ketua Yayasan Sahabat Rekan Sebaya, juga 
menegaskan bahwa masalah narkoba kini harus diakui sebagai masalah nasional karena ia bisa menghancurkan generasi muda (Republika, 1 Oktober 2001). Jika dilakukan penelitian, dengan melihat trennya, saat ini generasi muda yang menyalahgunakan narkoba tentu sudah berlipat beganda besarnya.

Jawa Barat, khususnya kota Bandung telah diidentifikasi sebagai daerah dengan tingkat peredaran dan penggunaan narkoba pada tingkat kritis sebagaimana di beberapa kota besar lainnya. Sebagaimana dikemukakan oleh Kapolri Mayjen. Pol. Rusdihardjo waktu itu, gerakan pemberantasan narkoba harus dimulai dari Jawa Barat, khususnya kota Bandung. Sebab, Bandung merupakan kota yang tingkat perederan dan penggunaan narkobanya tida kalah dengan Jakarta (Pikiran Rakyat, 4 September, 1999). Penelitian lain yang dilakukan oleh Dewan Pimpinan Cabang (DPC) Granat Surabaya - suatu organisasi masyarakat yang memiliki komitmen pada pencegahan dan penanggulangan narkoba - terhadap para siswa SMA di Surabaya juga memberikan temuan yang mengejutkan. Penelitian tersebut memperoleh temuan bahwa dari 140 SMA negeri dan swasta yang diteliti, sebanyak 70\% (98 sekolah), diidentifikasi telah terjamah narkoba (Jawa Pos, 23 Agustus, 2001).

Banyak data yang menegaskan bahwa di antara pengguna dan sasaran peredaran narkoba yang paling besar adalah kelompok usia remaja, umumnya siswa sekolah menengah, bahkan anak-anak usia sekolah dasar juga telah terjamah narkoba. Sebagai contoh, dari data yang diambil dari Rumah Sakit Ketergantungan Obat, sebagaimana dikemukakan oleh Hawari, seorang pengamat penyalahgunaan narkoba, secara keseluruhan dikemukakan, diantara korban narkoba, yang paling besar dari kalangan pelajar (SD, SMP, dan SMU), yakni $92 \%$ dari seluruh penderita (Bisnis Indoesia, 12 Spetmebr, 1999). Penelitian yang dilakukan oleh Tim Kelompok Kerja Pemberantasan Penyalahgunaan Narkoba yang dibentuk oleh Direktorat Pembinaan Kesiswaan Departemen Pendidikan Nasional, seperti dikemukakan oleh Monintjo, Ketua National Drug Abuse Prevention Center (NDPC), memperoleh temuan bahwa sekitar $70 \%$ dari 4 juta korban narkoba adalah anak usia sekolah, antara usia 14-20 tahun (Media Indonesia, 11 Februari 2000). Jika temuan tersebut benar, berarti pada tahun 2000 penyalahgunaan nar- koba oleh para siswa meningkat sekitar $100 \%$ dalam kurun waktu empat bulan, sebab data dari Departemen Pendidikan Nasional pada bulan November 1999 menyatakan dua juta siswa terlibat dalam penyalahgunaan narkoba. Dari data tersebut, siswa Sekolah Menengah Atas (SMA) tercatat sebagai kelompok usia yang paling banyak menggunakan narkoba (Media Indonesia, 11 Februari 2000). Berdasarkan data tersebut kita dapat memprediksikan berapa jumlah korban narkoba untuk saat ini.

Dengan mengingat peran penting generasi muda sebagai aset bangsa, maka semua pihak, melalui keahliannya di bidang masingmasing, perlu memberikan kontribusinya bagi penyelematan generasi muda khususnya kaum remaja, baik berupa pemikiran maupun tindakan nyata.

Banyak cara telah dilakukan untuk menanggulangi peredaran dan penggunaan narkoba baik oleh pemerintah maupun oleh beberapa organisasi masyarakat. Demikian pula, upaya penanggulangan narkoba juga dapat kita temukan di berbagai lembaga pendidikan mulai dari tingkat SD hingga perguruan tinggi, dan di beberapa instansi pemerintah maupun swasta. Banyak spanduk bertuliskan penolakan narkoba yang dipasang di beberapa sekolah dan kantor-kantor. Hasil-hasil yang dapat diamati mengindikasikan adanya ketidak berhasilan - untuk tidak menyatakan gagal - dari berbagai upaya tersebut. Indikasi ini dapat kita tetapkan setidaknya dengan melihat angka korban narkoba yang semikin meningkat. Fakta ini tentu saja mendesakkan suatu kebutuhan akan perlunya menemukan dan mengembangkan upaya-upaya alternatif baru atau suatu model intervensi yang lebih menjanjikan. Dan tulisan ini dimaksudkan untuk mengusulkan suatu model konseptual alternatif yang dideskripsikan berdasarkan perspektif psikologi perkembangan.

\section{PEMBAHASAN}

Dari perpsektif perkembangan, berbagai bentuk gejala perilaku - adaptif maupun tidak adaptif - dikonseptualisasikan sebagai hasil dari proses-proses perkembangan dalam rangka menuju peran orang dewasa yang sehat. Terdapat banyak variabel internal maupun eksternal, baik yang bekerja sendiri maupun saling mempengaruhi, yang memainkan peran pen- 
ting dalam mempengaruhi hasil-hasil perkembangan. Sebagai contoh, dari perspektif interaksionis (Freudian, Piaget, Erikson, Kohlberg), perilaku/perkembangan dipandang sebagai fungsi dari kekuatan-kekuatan individu dan pengaruh lingkungan/konteks sosial (dalam Lerner \& Hultsch, 1984; Papalia \& Olds, 1995; Steinberg, 1993, 2002). Berdasakan pada konsepsi ini maka penyalahgunaan narkoba merupakan satu bentuk perilaku yang dihasilkan oleh interaksi antara kekuatan-kekuatan dari dalam individu dan berbagai pengaruh lingkungan yang tidak menguntungkan (tidak kondusif) bagi individu untuk berkembang secara sehat. Sebagai contoh, anggaplah seorang remaja akhirnya bterlibat dalam penyalahgunaan narkoba setelah ia memperoleh tekanan dari kelompoknya untuk menggunakan narkoba. Secara internal, dapat diduga remaja tersebut tak memiliki (belum mencapai) kemandirian pribadi, tak memiliki kemampuan kognitif yang tak mencukupi untuk membuat penalaran logis tentang efek jangka panjang dari narkoba tersebut, atau tak memiliki kompetensi sosial untuk menolak/melawan tekanan tersebut.

Pada perkembangan sebelumnya remaja tersebut mungkin juga belum atau tak membuat internalisasi nilai-nilai luhur masyarakat. Mungkin juga, remaja tersebut juga telah terkondisikan dengan narkoba oleh teman-teman dekatnya yang mengkonsumsi atau memodelkan penggunaan narkoba, atau oleh efek menyenangkan yang ia peroleh setelah mengkonsumsi narkoba, yang mengalahkan efek tak menyenangkan yang diterimanya dari orang tua atau sekolahnya yang mungkin berupa teguran atau hukuman. Sebaliknya, remaja yang telah membangun kepribadian yang kuat, yang telah mencapai kemandirian pribadi dan kemampuan kognitif yang memadai, cenderung terhindar dari tindakan yang merugikan dirinay sendiri mau-pun orang lain dan lingkungan sosialnya.

Karena terdapat begitu banyak variabel yang mempengaruhi hasil-hasil perkembangan, maka terdapat peluang bagi para profesional yang bekerja dalam lapangan intervensi psikologis atau intervensi sosial, termasuk di dalamnya para pekerja sosial, konselor, dan psikolog untuk merancang suatu program intervensi yang tepat guna menangani berbagai bentuk perilaku menyimpang dengan cara menangani variabel - variabel perkembangan. Banyak ahli perkembangan yang setuju dengan konsepsi Erikson, salah seorang teoris perkembangan, bahwa pencarian identitas merupakan salah satu aspek psikosial yang paling krusial pada periode remaja. Sebagaimana dikemukakan oleh Erikson (1968), dalam teori perkembangan psikososialnya, tugas perkembangan utama pada periode remaja adalah mencapai identitas diri yang koheren atau realitis. Remaja dikatakan mencapai identitas jika ia mampu memecahkan konflik (krisis) atara identity vs. identity confussion (dalam Papalia \& Olsd, 1995; Steinberg, 1993; Fuhrmann, 1990). Identitas (self identity atau ego identity) menunjuk pada "self-determination," atau "self-definition." Dalam bentuknya yang sederhana, identitas menunjuk pada suatu jawaban tentang "Siapa saya?" "Akan menjadi apa saya?" "Dimana tempat saya?" dan sebagainya.

Dengan menggunakan asumsi bahwa pencarian identitas merupakan tugas perkembangan yang krusial pada masa remaja, dan kerangka pemikiran bahwa terdapat hubungan antara perilaku penyalahgunaan narkoba dan keberhasilan dalam menangani krisis identitas, maka suatu upaya untuk menganggulangi penyalahgunaan narkoba dapat dilakukan dengan cara memberikan intervensi terhadap proses pencarian identitas. Dasar pemikiran yang digunakan adalah bahwa dengan memiliki aktivitas untuk menemukan identitas dan dengan memiliki identitas yang koheren, individu lebih mungkin mengarahkan perilakunya kearah pencapaian tujuan yang positif sesuai dengan komitmen identitasnya.

Secara umum intervensi dilakukan untuk maksud menanggulangi penyalahgunaan narkoba di kalangan remaja. Secara khusus, intervensi ini dimaksudkan untuk membantu remaja mencapai identitas diri yang koheren atau realistis dalam berbagai bidang kehiduapan, dan capaian ini pada giliranya dapat memberikan dampak positif untuk mencegah remaja melakukan berbagai tindakan yang merusak diri dan lingkungan termasuk didalamnya menyalahgunakan narkoba.

Untuk memberikan penjelasan teoretik berkenaan dengan efek intervensi identitas pada pencegahan penyalahgunaan narkoba pada remaja akan digunakan teori perkembangan psikosisial Erik Erikoson, khususnya tentang perkembangan psikososial pada periode remaja, yakni resolusi krisis identitas. 
Dalam teori perkembangan psikososialnya, Erikson (1959, 1963, 1968), menyatakan bahwa di sepanjang hayatnya (rentang hidup) manusia berkembang melalui delapan tahap krisis psikososial (Archer, 1994; Erikson, 1968; Marcia, dkk., 1993; Papalia \& Olds, 1995; Steinberg, 2001). Setiap krisis psikososial tersebut membatasi "usia" atau "tahapan" dalam rentang hidup (lihat bagan 1). Setiap tahapan krisis menyajikan suatu macam tantangan yang harus dipecahkan oleh individu sebagai suatu tugas perkembangan. Krisis ini bersifat normatif, dalam arti bahwa ia tak dapat dihindarkan oleh setiap individu untuk tumbuh dan berkembang menjadi dewasa. Setiap krisis memiliki kutup positif dan negatif. Misalnya, krisis psikososial pada usia remaja adalah konflik antara identitas (positif) versus kebingungan identitas (kutup negatif). Setiap tahapan krisis juga memiliki hubungan kausal, dalam arti bahwa keberhasilan dalam menangani setiap tahapan krisis akan dipengaruhi oleh keberhasilan dalam menangani krisis sebelumnya dan seterusnya mempengaruhi keberhasilan dalam menangani krisis berikutnya. Misalnya, keberhasilan dalam menangani krisis identitas versus kebingungan akan dipengaruhi oleh keberhasilan atau kegagalan dalam menangani krisis pada periode anak. Jika individu gagal memperoleh kepercayaan, otonomi, dan keterampilan industri, mereka akan mengalami kesulitan untuk membangun suatu identitas yang koheren. Jadi, resolusi yang sehat pada tahapan-tahapan krisis sebelumnya akan mempengaruhi resolusi yang sehat pada tahapan perkembangan berikutnya. Dari delapan tahapan psikososial tersebut, membangun suatu identitas yang koheren merupakan krisis psikososial yang utama.

Tabel 1. Delapan Tahapan Perkembangan Psikososial Menurut Perspektif Erikson

\begin{tabular}{ll}
\hline \multicolumn{1}{c}{ I Infancy } & \multicolumn{1}{c}{ Trust Vs. Mistrust } \\
\hline II Early Childood & $\begin{array}{l}\text { Autonomy Vs. Shame, } \\
\text { Doubt }\end{array}$ \\
III Play age & Initiative Vs. Guilt \\
IV School age & Industry Vs. Inferiority \\
V Adolecence & Identity Vs. Identity \\
& Difussion \\
VI Youn adult & Intimacy Vs. Isolation \\
VII Adulthood & Generativity Vs. Self- \\
& Absorpt \\
VIII Mature age & Integrity Vs. Disgust, \\
& Despair \\
\hline
\end{tabular}

Sebagaimana dapat dibaca pada tabel 1 , dimensi psikososial yang tampak pada periode remaja adalah identitas pada kutub positif dan kebingungan identitas pada kutup negatif. Mengikuti tahapan psikososial tersebut, tugas perkembangan yang harus diselesaikan oleh remaja adalah membuat konsolidasi semua pengetahuan tentang diri yang telah mereka peroleh (misalnya sebagai anak laki atau anak perempuan, siswa yang cerdas, ahli musik, periang, membosankan, dan sebagainya) dan mengintegrasikan semua pengetahuan diri tersebut ke dalam suatu identitas personal yang memperlihatkan adanya kesadaran tentang masa lampau dan masa depan (dalam Hjelle \& Ziegler, 1991).

Pencarian identitas (search for identity) meskipun merupakan proses yang panjang yang telah dimulai sejak usia anak dan terus berlangsung hingga masa dewasa, pada masa remaja proses tersebut memiliki karakteristik yang berbeda dan paling menonjol (Papalia \& Olds, 1995; Steinberg, 2002). Menurut Steinberg, menonjolnya proses pencarian identitas pada periode remaja tersebut disebabkan oleh adanya perubahan-perubahan pada aspek biologis, kognisi, dan sosial yang menandai masa transisi dari dunia anak yang belum matang menuju peran orang dewasa yang matang. Individu yang mencapai identitas koheren (berhasil) adalah mereka yang memiliki konsep diri yang realistik yang berisikan penguasaan lingkungan baik secara fisik maupun kognitif dan diakui oleh masyarakat disekitarnya, dan mengakui hubungan dirinya dengan orang lain serta keindividualitasan/keunikan dirinya ( $\mathrm{Fu}-$ hrmann, 1990).

Menurut Erikson (Erikson, 1968: Lopez, 1992), keberhasilan dalam menyelesaikan krisis antara identitas versus kebingungan identitas adalah remaja mencapai suatu identitas diri yang stabil dan positif, atau koheren dan self-definition yang bermakna. Keberhasilan ini akan memfasilitasi penyelesaian krisis psikososial pada tahapan berikutnya (dewasa). Di sisi lain, kegagalan dalam mengatasi krisis menyebabkan remaja membentuk identitas yang tidak jelas atau kabur (mengalami kebingungan identitas). Pada gilirannya, kegagalan ini akan menyebabkan remaja mengalami berbagai problem psikososial.

Menurut pendekatan Marcia (Archer, 1994; Marcia, dkk., 1993; Steinberg, 2003) keberhasilan dan/atau kegagalan dalam mencapai 
suatu identitas yang koheren dapat diukur dari dua faktor: ada tidaknya eksplorasi/eksperimentasi dan komitmen identitas. Persilangan antara tingkat eksplorasi dan tingkat komitmen menghasilkan empat status identitas: prematur, dini, tertunda, dan koheren (lihat bagan 2). Eksperimentasi dan komitmen identitas, menurut Marcia, berhubungan dengan berbagai bidang (domain) kehidupan seperti: vokasional, religi, ideologi, hubungan sosial; serta konflik antara peran-peran tersebut. Berbagai peran dalam berbagai bidang kehidupan mungkin dieksplorasi dan dicoba, kemudian diterima, ditolak, atau dimodifikasi sebagai upaya membentuk konsep diri yang terintegrasi (Atkinson, dkk., 1992).

Tabel 2. Model Status Identitas dari James Marcia

\begin{tabular}{cccc}
\hline & \multicolumn{2}{c}{ Komitmen } \\
\cline { 2 - 3 } & Rendah & Tinggi \\
\hline \multirow{2}{*}{ Ekplorasi } & Rendah & Difusi & Premature \\
\cline { 2 - 4 } & Tinggi & Tunda & Tercapai \\
\hline
\end{tabular}

Berbagai masalah psikososial yang disebabkan oleh kegagalan dalam mencapai identitas digambarkan oleh Erikson (1968) dalam skema topografi. Dalam skema ini remaja yang memiliki identitas difusi akan memperlihatkan karakteristik sebagai berikut:

Membelah ego/dirinya dan kehilangan nentralitas, suatu perasaan diri yang menyebar dan bingung (tak terintegrasi). Tidak siap membuat komitmen, tidak ingin membuat pilihan karir, dan menolak untuk menyebutkan apa yang ia ketahui tentang siapa dirinya, memiliki perasaan tidak mampu, tergantung dan mudah dipengaruhi oleh orang yang memiliki kekuasaan atau otorita. Jika mereka memiliki kebingungan dalam peran seksual, remaja akan cenderung melakukan pekerjaan yang berlebihan, tak bisa berkonsentrasi, melakukan pekerjaan atau aktivitas yang merusak diri, suka membolos dari sekolah bahkan keluar dari sekolah, suka keluar malam dan begadang, menghindari kontak sosial, suka berkelompok, tidak toleran terhadap orang lain, suka berbuat iseng, berhubungan seksual dengan siapa saja, suka mencoba-coba perilaku aneh/ganjil, dan melanggar hukum. Pada umumnya, remaja yang memiliki identitas difusi memiliki perasaan aneh terhadap dirinya sendiri dan lingkungannya, dan merasa tidak menyenangi siapapun
(Fuhrmann, 1990). Hjelle \& Ziegler (1992), juga mengemukakan bahwa krisis identitas sangat sering ditandai oleh ketidak mampuan individu untuk memilih suatu karir atau pendidikan lanjutan. Dikemukakan lebih lanjut bahwa banyak remaja yang memperlihatkan difusi identitas tersebut juga memperlihatkan berbagai problem emosional dan psikologis seperti perasaan bersalah yang mendalam, disorganisasi kepribadian, dan kehilangan pegangan hidup. Mereka juga merasa tak berdaya, kehilangan jati diri, dan bahkan membentuk suatu identitas negatif, suatu identitas yang bertentangan dengan apa yang diharapkan oleh orang tua, kelompok teman sebaya, atau masyarakat. Erikson juga yakin bahwa beberapa perilaku melanggar hukum (delinquent) juga disebabkan oleh adanya krisis identitas tersebut.

Dengan melakukan intrervensi untuk membantu remaja mencapai identitasnya maka berbagai bentuk karakteristik negatif tersebutb tak akan terjadi dan kondisi ini berpotensi membawa remaja berkembang menjadi orang dewasa yang sehat dan terhindar dari penyalahgunaan narkoba.

Suatu intervensi psikologis untuk membantu perkembangan identitas dimungkinkan sebab pencarian identitas memiliki dimensi sosial. Formasi identitas dipengaruhi oleh cara lingkungan sosial merespon atau memberikan umpan balik terhadap identitas yang dideklarasikan oleh remaja, sebab aspek kunci dalam memecahkan krisis identitas terletak pada interaksi antara remaja dengan orang lain (Erikson, 1968; Steinberg, 2002). Reviu terhadap berbagai model dan perspektif teoretik sebagaimana dilakukan oleh Phillips (1992) mendatangkan suatu simpulan bahwa jika digabungkan, berbagai perspektif teoretik menyatakan bahwa formasi identitas itu sendiri merupakan suatu proses dan hasil ekplorasi dan interaksi individu dengan berbagai macam aspek lingkungan. Melalui umpan balik yang diterima dari orang lain, remaja dapat memilih di antara elemen-elemen yang menurutnya menjadi bagian dari identitas dirinya. Orang lain, dengan siapa remaja berinteraksi, berfungsi sebagai cermin yang dapat merefleksikan kembali informasi remaja tentang siapa dirinya. Melalui reaksi orang lain, remaja dapat mempersepsi dirinya apakah ia termasuk orang yang pandai atau bodoh, menyenangkan atau membosankan, ramah atau pendiam, pada bi- 
dang apa yang kompeten dan pada bidang apa ia tidak kompeten, dan sebagainya. Dalam hal ini, Erikson menegaskan bahwa formasi identitas merupakan suatu proses mental disamping proses sosial, dan memberikan penekanan yang kuat pada masyarakat (khususnya yang memeiliki pengaruh pada individu) dalam membentuk identitas remaja. Identitas final remaja, dipandang sebagai hasil dari pengakuan bersama antara remaja dan masyarakat.

\section{RANCANGAN STRATEGI INTERVENSI}

Strategi intervensi menunjuk pada suatu rencana kerja atau langkah-langkah prosedural yang dikembangkan oleh profesional untuk membantu individu atau kelompok individu berubah dari perilaku tak adaptif (tak diharapkan) menuju perilaku adaptif (yang diharapkan) (Cormier \& Cormier, 1985). Berdasarkan definisi strategi intervensi tersebut dan dengan mendasarkan kerangka kerja yang telah ditetapkan (model perkembangan identitas Erikson), serta berbagai strategi intervensi identitas sebagaimana diusulkan oleh Archer (1994), model rancangan intervensi identitas untuk tujuan mengendalikan penyalahgunaan narkoba sebagaimana diusulkan dalam tulisan ini memiliki aspek-aspek berikut.

Tujuan umum intervensi adalah untuk mencegah remaja dari kemungkinan menyalahgunakan narkoba. Sedangkan tujuan khusus adalah membantu remaja menemukan berbagai kegiatan yang mendukung kearah eksplorasi/ eksperimentasi identitas dan menjauhi kegiatan yang mengarah pada penggunaan narkoba, membuat komitmen yang realistis, dan membantu remaja menemukan dan melaksanakan kegiatan yang mengarahkan pada pelaksanaan komitmen/keputusan identitas.

Sasaran umum intervensi adalah individu yang dapat diidentifikasi sebagai remaja menurut batasan perspektif perkembangan. Termasuk ke dalam kelompok ini utamanya adalah para siswa SLTP dan SMTA. Meskipun tujuan utamanya aalah pencegahan, remaja yang bisa terlibat dalam program ini bukan hanya remaja yang belum mengenal narkoba, tetapi bisa juga mereka yang diidentifikasi telah mencoba-coba (berkesperimentasi dengan narkoba, menggunakan secara kadang-kadang), dan mereka yang telah terbukti kecanduan narkoba pada tingkat ringan.
Program intervensi identitas dapat diadministrasikan melalui format individual maupun kelompok, meskipun format kelompok lebih dianjurkan karena telah terbukti lebih efektif khususnya untuk kelompok sasaran remaja (Archer, 1994). Konseling kelompok dipandang sangat potensial untuk digunakan.

Di dalam konseling kelompok ini menggunakan model T-F-A (thinking, feeling, action), artinya fokus intervensi bisa pada faktor kognisi, emosi, atau perilaku, tergantung pada karakteristik yang diidentifikasi yang dipandang paling dominan pada individu (Hackney \& Cormier, 2001). Meskipun demikian, tanpa bermaksud menurunkan keefektifan pendekatan yang lain, untuk kelompok remaja dengan latar belakang budaya Indonesia, pendekatan perilaku dipandang lebih cocok karena model ini memiliki langkah-langkah prosedural dan struktur yang direktif dan jelas. Ini dipandang cocok karena karakteristik remaja kita umumnya cenderung buang-buang waktu dan tidak efisien. Karena distruktur dengan jelas, mulai dari tujuan dan proses, maka hasil-hasil program akan lebih mudah untuk dievaluasi.

Konseling kelompok perilaku dapat dilaksanakan dengan berbagai model. berikut ini salah satu contoh model yang diadaptasikan dari Rose $(1977,1983)$ dan Hollander dan Kazaoka (1988) sebagai berikut:

Membentuk kelompok. Pada tahap ini profesional membentuk kelompok konseling kelompok (boleh satu kelompok atau lebih tergantung pada jumlah sasaran yang akan ditangani). Ukuran kelompok bisa bervariasi, antara 2- 14 remaja. Kelompok boleh dikomposisikan secara homogen atau hiterogen pada basis jenis kelamin atau tingkat keterlibatan narkoba, tergantung pada kondisi praktis di lapangan dan pertimbangan profesional yang mengadministrasikannya. Remaja yang terlibat dalam konseling kelompok ini disebut anggota kelompok. Setiap kelompok selanjutnya ditangani oleh satu konselor yang telah berpengalaman dalam mengadministrasikan konseling kelompok. Konselor yang mengadministrasikan konseling kelompok disebut pemimpin kelompok.

Memotivasi kelompok/wawancara awal. Pada tahap ini pemimpin kelompok melakukan wawancara awal kepada seluruh calon anggota untuk memastikan bahwa mereka bersedia untuk terlibat secara sukarela dan bekerja da- 
lam kelompok. Kepada para calon anggota diberikan informasi tentang proses konseling dan tujuan yang dapat diharapkan dari proses tersebut, berapa lama kerja kelompok akan berlangsung, jumlah sesi, dan siapa saja yang terlibat. Pada tahap ini pemimpin kelompok juga mendorong para anggota kelompok untuk mengeksplorasi problem-problem berkaitan dengan status identitasnya dan apa yang telah mereka lakukan berkaitan dengan formasi identitas. Pemimpin kelompok juga menekankan pentingnya kerjasama dan kebersamaan dalam kelompok kepada para anggota.

Mengembangkan keterbukaan/mengembangkan keterlibatan. Pada tahap ini pemimpin kelompok mendorong setiap anggota untuk saling mengemukakan jati diri mereka dalam bebagai domain kehidupan dan mendorong anggota lain untuk memberikan respek dengan cara mendengarkan secara aktif dan memberikan umpan balik yang konstruktif. Untuk maksud ini pemimpin kelompok memodelkan bentuk perilaku yang diharapkan tersebut kepada kelompok dan meminta salah satu atau beberapa anggota kelompok untuk menirukannya. Selanjutnya, pemimpin kelompok mendorong seluruh anggota untuk membuka diri dan memberikan umpan balik.

Membangun kerangka kerja perilaku pada partisipan/anggota kelompok. Setelah pemimpin kelompok memperoleh keyakinan bahwa kelompok dapat berjalan, yang dibuktikan oleh adanya kesediaan untuk saling terbuka dan memberikan umpan balik, pemimpin kelompok memperkenalkan kepada anggota tentang kerangka kerja perilaku dalam proses kelompok. Satu aspek kunci yang diperkenalkan oleh pemimpin kelompok kepada anggota adalah bahwa perilaku disebabkan oleh suatu situasi atau peristiwa yang mendahului (anteseden) dan diperkuat atau dipertahankan oleh suatu konsekuensi (penguatan), dan problem perilaku terjadi karena adanya kesalahan dalam belajar. Untuk menangani Problem tersebut, individu harus mengoreksi kesalahan belajar tersebut (relearning). Initinya, pemimpin kelompok memperkenalkan kepada anggota tentang bagaimana proses kelompok akan bekerja berdasarkan prinsip-prinsip teori perilaku.

Menetapkan struktur kelompok. Pada tahap ini pemimpin kelompok memperkenalkan struktur kepada kelompok. Struktur dirumuskan dalam suatu kontrak perilaku secara tertulis disetujui oleh seluiruh anggota kelompok.
Implementasi strategi/teknik perilaku. Pada tahap ini, pemimpin kelompok menerapkan berbagai strategi atau teknik perilaku untuk membelajarkan para anggota kelompok tentang cara membangun formasi identitas melalui eksplorasi dan komitmen. Secara operasional, teknik-teknik tersebut diarahkan untuk membantu siswa belajar berbagai keterampilan perilaku yang kondusif bagi pencarian identitas. Beberapa teknik perilaku yang digunakan antara lain adalah pemodelan, restrukturisasi kognitif, rehearsal, tranfer dan generalisasi, dan penguatan. Teknik-teknik tersebut digunakan secara tunggal atau secara kombinatif sesuai dengan karakteristik dan kebutuhan klien.

Proses konseling dilaksanakan selama 8 kali pertemuan, dengan satu kali pertemuan setiap minggu. Setiap pertemuan berlangsung antara 90 hingga 120 menit. Frekuensi dan durasi pertemuan ini mengikuti beberapa format konseling kelompok sebagaimana dikemukakan oleh beberapa penulis dalam lapangan konseling dan psikoterapi (misalnya George \& Cristiani, 1981; Gladding, 1995; Ohlsen, 1970).

Mendorong generalisasi perilaku yang dihasilkan. Setelah berhasil dalam memodifikasi perilaku/memperoleh keterampilan perilaku dalam seting kelompok berkaitan dengan eksplorasi dan komitmen identitas, pemimpin mendorong setiap anggota untuk mempraktekkan perilaku tepat tersebut dalam seting natural di luar kelompok. Ini dilakukan dengan memberikan tugas rumah (homework assignment) kepada para anggota. Untuk memfasilitasi tugas ini, pemimpin kelompok memberikan suatu format yang dapat digunakan oleh anggota untuk membuat laporan tentang berbagai peristiwa psikologis yang dialaminya selama menjalankan tugas rumah tersebut. Tugas ini berhubungan dengan eksplorasi identitas.

Mempertahankan perubahan perilaku yang dihasilkan. Pemimpin kelompok mengajak kelompok untuk mendiskusikan hasilhasil laporan tentang pelaksanaan tugas rumah sebagaimana dibuat oleh setiap anggota. Selanjutnya, pemimpin kelompok menginstruksikan dan mendorong anggota untuk tetap mempraktekkan perilaku dan menggunakan format se-bagai alat pantauan diri, dan secara berangsur-angsur mengurangi ketergantungan akan dukungan bantuan orang lain dan dapat mandiri dalam menghadapi setiap kesulitan. 
Evaluasi. Evaluasi dimaksudkan untuk membuat justifikasi tentang efektif tidaknya program intervensi yang dirancang untuk mengendalikan penggunaan narkoba di kalangan para siswa. Evaluasi didasarkan pada data yang diukur setelah satu bulan konseling diakhiri. Jeda waktu ini dimaksudkan untuk memberkan kesempatan kepada para anggota kelompok dalam proses generalisasi serta dalam melakukan eksplorasi identitas. Meskipun rentang jeda waktu ini dapat diperdebatkan, dalam pemikiran penulis, waktu satu bulan tersebut cukup bagi subyek untuk membangun retensi dan menerapkan keterampilan perilakunya yang baru. Sesuai dengan tujuan program, sasaran pengukuran adalah tingkat eksplorasi identitas dan koherensi dalam membuat komitmen identitas. Sedangkan perilaku terlibat (keterlibatan) subyek dalam proses kelompok, diamati di sepanjang kerja kelompok. Aspek-aspek perilaku tersebut dapat dilihat pada bagian definisi operasioanalnya masing-masing. Sumber data adalah subyek yang menerima perlakuan, orang tua, guru, konselor sekolah, dan masyarakat. Data evaluasi - frekuensi perilaku/aktivitas eksplorasi identitas dan frekuensi penggunaan narkoba - dikumpulkan melalui metode observasi, angket, dan wawancara. Analisis dampak perlakuan dapat dilakukan dengan menggunakan pendekatan kuantitatif, kualitatif, atau keduanya.

Program konseling ini melibatkan sumber-sumber sosial untuk memberikan dukungan sosial dan memfasilitasi keberhasilan. Sumber-sumber sosial adalah orang tua, guru, dan konselor sekolah, serta masyarakat lain yang signifikan. Sumber-sumber sosial ini khususnya dilibatkan dalam program pemberian tugas rumah, dalam bentuk memberikan dukungan sosial (penguatan) dan memberikan bantuan dalam kegiatan eksplorasi.

\section{SIMPULAN}

Dari apa yang telah dikemukakan dapat dibuat beberapa simpulan berikut. Kesimpulan yang pertama adalah bahwa penyalahgunaan narkoba di kalangan remaja perlu mendapatkan perhatian yang serius dari semua pihak karena prevalensinya dinilai telah membahayakan kelestarian bangsa. Penyalahgunaan narkoba dipandang sebagai suatu gangguan perilaku yang bisa dicegah atau dimodifikasi dengan menggunakan suatu kerangka kerja kon- septual yang memadai. Perspektif perkembangan merupakan salah salah satu kerangka kerja yang bisa digunakan. Teori perkembangan psikososial Erikson, khususnya yang membahas tentang krisis identitas pada periode remaja dipandang dapat menjadi kerangka kerja konseptual yang memadai guna mengkaji penyalahgunaan narkoba di kalangan remaja dan sebagai landasan untuk mengembangkan program intervensinya. Dasar pemikirannya adalah bahwa jika remaja berhasil dalam menangani krisis identitas (satu tahapan dalam perkembangan psikososial), maka ia akan lebih mungkin mengarahkan perilakunya pada pencapaian tujuan-tujuan yang positif dan konstruktif sehingga cenderung terhindar dari berbagai perbuatan menyimpang, termasuk di dalamnya penyalahgunaan narkoba. Intervensi dapat diberikan pada level individu atau kelompok. Konseling kelompok perilaku merupakan salah satu format intervensi kelompok yang memiliki beberapa kelebihan dan perlu dipertimbangkan.

\section{DAFTAR PUSTAKA}

Archer, S.L. (1994). Intervention for Adolescent Identity Development. London: Sage Publication.

Brown, S.D., \& Lent, R.W. (1992). Handbook of Counseling Psychology. $2^{\text {nd. }}$ ed. New York: John Wiley \& Sons.

Fuhrmann, B.S. (1990). Adolescence. $2^{\text {nd }}$ ed. Illinois: Scott, Foresman/Little, Brown Higher Education.

George, Rickey L. dan Cristiani, TS. (1981). Theory, Methods, and Process of Counseling and Psychotherapy. Englewood Cliffs, New Jersey: Prentice Hall, Inc.

Hackney, H.L., \& Cormier, L.S. 2001. The Professional Counselor. A Process Guide to Helping.

Gladding, Samuel T. (1995). Groups Work: A Counseling Specialty. $2^{\text {nd. }}$ Ed. New Jersey: Merrill, an Imprint of Prentice Hall

Hjelle, Larry A, \& Ziegler Daniel J. (1991). Personality Theories. Basic Assumtion, Research, and Applications. $3^{\text {rd. }}$ Ed. New York: McGraw Hill International Editions.

Huffman, K., \& Vernoy, M., \& Williams, B. (1991). Psychology in Action. $2^{\text {nd. }}$ Ed. New York: John Wiley \& Sons. 
Kendall, N. \& Ford. (1997). Clinical Psychology, Scientific and Professional Dimension. New York: McGraw Hill International Editions.

Lerner, R.M., \& Hultsch, D.F. (1983). Human Development. A Life Span Perspective. New York: McGraw HillBook Co.

Lopez, F.G. (1992). Family Dynamics and Late Adolescent Identity Development. New York: John Wiley \& Sons, Inc.

Marcia, J.E., \& Waterman, A.S., \& Archer, S.L., \& Orlofsky, J.L. (1993). Ego Identity. A Handbook for Psychological Research. New York: Springer Verlag.

Ohlsen, M.M. (1970). Group Counseling. New York: Holt, Rinehart and Winston, Inc.

Papalia, Diane E., \& Olds, Sally W. (1995).
Human Development. $6^{\text {th }}$ ed. New York: McGraw-Hill, Inc.

Steinberg, Laurence. (1993). Adolescence. International ed. New York: McGraw Hill., Inc.

"70 \% Pencandu narkoba adalah siswa." Media Indonesia, 11 Februari 2000.

"Penyalahgunaan narkoba terbesar di kalangan siswa." Bisnis Indonesia, 12 September 1999.

"Jangan biarkan mereka kecanduan." Republika, 1 Oktober, 2000.

"Kobarkan perang lawan narkoba ." Pikiran Rakyat, 4 September 1999.

"Meningkat, peredaran narkoba."

Pikiran Rakyat, 7 Desember, 2001 